Bulletin of the Transilvania University of Braşov - Special Issue

Series VII: Social Sciences • Law • Vol. 13(62) No. 1 - 2020

https://doi.org/10.31926/but.ssl.2020.13.62.3.14

\title{
BRAȘOV, CITY OF LOST CANDIDACIES. CASE STUDY
}

\section{Lorena OPRICA ${ }^{1}$}

\begin{abstract}
During 2015-2018 Brașov lost each of the three major competitions in which it participated (2020 Youth Olympic Games, 2021 European Capital of Culture and Capital of Youths from Romania in 20192020). Particular aspects have drawn our attention in the processes of these candidacies and made us ask ourselves "what is Brașov" and what Brașov identifies with? This article is a short case study about how Brașov prepared its candidacy for the 2021 European Capital of Culture competition and how Brașov is perceived.
\end{abstract}

Key words: identity, perceptions, creative city, destination branding, memorable experiences.

\section{Introduction}

In between 2015-2018 the city of Brasov applied to be the host of three major events (the Youth Olympic Games of 2020, the European Capital of Culture for the year 2021 and the Youth Capital of Romania 2019-2020). And every time it lost.

The title of "Youth Capital of Romania 2019-2020" was lost in favour of lasi, that of European Capital of Culture for the year 2021 in favour of the city of Timisoara and the organization of the 2020 Youth Olympic Games was lost in favour of the city of Lausanne, Switzerland.

Particularly interesting is the difference between the presentations of the two candidates for the organization of the Youth Olympic Games of 2020, lost in front of Lausanne. The official presentations are available as a video on You Tube for both Brasov and Lausanne. If the city of Brașov presented itself with what it has: slopes, ice rinks, the experience of organizing the 2013 Youth Olympic Festival (FOTE), etc., Lausanne presented its identity, and emphasized the highest quality education, the opportunities offered to young people, for the joy of living in this city.

The major difference in the presentations made for the two cities is the focus on 'WE HAVE' (Brașov) versus 'WE ARE' (Lausanne). Analyzing these presentations, I asked the question 'Who is / What is Brașov?'. To answer this question, for this particular paper, I have used as methodology the secondary data analysis.

\footnotetext{
${ }^{1}$ National School for Political Administrative Studies, lorena@cercetari.ro.
} 


\section{Theoretical Arguments}

In Schopflin's vision there are four dimensions in which identities are structured: state identity, civil society activities (major generators of identity elements are: individuals, NGOs and groups, by trading interests, forming currents, aspirations, expressing opinions, etc.,) ethnicity (which includes several elements: solidarities, common religions, etc.), the international and, more recently, the global dimension (Botezat, 2012).

Another approach is to differentiate between Place Identity and Destination Identity. The professionals in the hospitality industry are using the term 'location ' with the meaning of 'destination ' being taken from the English 'location'. This new definition of the term has also been included in the Explanatory Dictionary of the Romanian Language after the 2009 edition. The 'location' identity refers to the destination identity/brand. Place identity refers to the identity of the 'territorial administrative space', in the sense of county, city, commune or region. In most public discourses, hospitality professionals use the term "brand" of place/location to express the idea of a place or location.

The brand definition given by the American Marketing Association as „, a name, a term, a sign, symbol or drawing, or all combinations that tend to identify the goods and services of a seller or group of sellers and differentiate them from other competitors" is often a starting point in brand management. The brand value was applied to products, corporations, destinations and, more recently, locations. (A.M.A., 2019)

The definition of the destination brand (Ritchie \& Ritchie, 1998) is: name, symbol, logo, word, or other drawing that at the same time identifies and differentiates a destination. Furthermore, it returns the promise of a memorable journey that is uniquely associated with the destination and also reinforces the memories of that trip. A clear distinction is made between the destination brand and the place brand. (Keer, 2006) identified a few essential things for local brand development:

- production of goods and services

- corporate headquarters

- foreign investment and export of products

- business in tourism and hospitality

- new residents.

The place brand is associated primarily with the desire inspired by the economic environment to position the city as positively as possible on a scale of mobility and abundance. Cities must be empathically shaped, conceptualized and brought to the attention of companies, residents and visitors, 'not dependent' on a place (Mommas, 2003). The place brand is more associated with the corporate brand than with the product brand. A place, a city, can be identified either with its industry, its way of life, or by association with other locations in terms of cluster (e.g. the Szekler Land), or in terms of architecture (in the sense of construction eg Saxon cities) (Kerr, 2006). In conclusion, the location identity is addressed to tourists, while the place identity is aimed at tourists as well as locals, by creating jobs, other than the tourism industry.

We can thus see that the professionals in the hospitality industry but also in the 
marketing industry are using the terms brand and identity as being interchangeable although, in reality, the brand is part of the identity. Creating the identity of a country is not the same as promoting tourism, promoting tourism is only part of a whole. (Kerr, 2006) This also applies to a city. In the process of developing and creating the identity of a city, at least in the western world, the elements 'creative', 'urbanism 'or 'experiences' are used.

\subsection{Creative city}

Creative City is a concept developed by Charles Landry in the 1980s in his book The Creative City, A Toolkit for Urban Innovators, which soon became a global movement for the development of cities. Charles Landry said that most cities are in transition, especially those with a history of industrial cities; they need to reinvent themselves to revitalize their economy in order to climb the value scale and become centers of knowledge (Landry, 2013).

\subsection{Elements of urbanism}

The design of a community, how it is designed has a major impact on human behavior and the way places are used. Urban design plays a vital role in promoting sustainable cities as an urban space structure and form, also having considerable influence on social, economic and environmental processes (Moțcanu-Dumitrescu, 2011). The quality design entails the creation of a sustainable environment. It means that we will be able to create areas / spaces / territories that are safe, in which you want to live / work / have fun and which can attract all ages and all categories.

\subsection{The city of 'experiences`}

A dominant approach in the West, which changes the stakes of the brand, both the location and the destination, but is little known and used by us, is that of the "experience". Gilmore \& Pine argue in their work Economics of Experience (Pine, B. J. \& Gilmore, J., 2010) that, unlike commodities, that are interchangeable, goods, that are tangible, services, that are intangible, experiences are memorable and customers are looking for the time and money needed to benefit from services that facilitate more memorable and valuable experiences.

Extrapolating to the topic of my research, we can say that the beneficiaries of a city (its inhabitants and visitors) are willing to spend more (energy, time, and money) to have 'memorable experiences in that city'. A city that offers memorable experiences is a valuable city in the eyes of its consumers and makes them more attached to it. Morgan \& Pritchard (2001) stated that in the tourism industry success will be granted by conquering the minds and the hearts of the customers, which means, in essence, to construct a powerful brand.

\section{Case Study}

Starting from Schopflin's vision of identity, we set out to analyze how the 'dimensions' of state and civil society influence the identity of Brasov. In a first stage, which we will 
present in this paper, we will inventory the actions of local authorities, individuals, NGOs and action groups. We are interested in finding out how structured, unitary or chaotic the action plan of the city's main actors (public authorities and initiative groups) is in the positioning action of the product called Brasov, and how these actions, unitary or not, strategic or not, influences the brand, in the broad sense of identity of the city of Brasov.

As I mentioned, the title of European Capital of Culture 2021 was granted to the city of Timisoara. In Brasov, this candidacy gave rise to several action groups and several voices that supported Brasov's participation with various arguments related to the city's tradition and culture. At the same time, this candidacy brought into the public debate a series of concepts that wanted to be the key element of the identity of Brasov.

These concepts, six in number ('Multiculturalism of the city of 10 names', 'Opera Prima - first book, first school, first grammar in Romanian, first print ...', 'Polycentric city of culture', 'From medieval to contemporary - a redefinition of cultural identity', 'Brașov stories, a new cultural geography' and 'Regeneration through culture'), could be studied and voted by the citizens of Brașov on the site Brasov2021.ro and were included in The Strategy for Culture of the Municipality of Brașov 2015-2030. Synthesis, strategy that can be consulted on the website of Brasov City Hall. Two of them drew attention: 'The multiculturalism of the city of the ten names', and 'Opera prima'.

In The multiculturalism of the city of the ten names Nazare (2017, pp. 324-326), proposes: "Let us imagine a circle in which the name of Brașov is written, and from it all 9 cardinal points start." Nazare identifies in his proposal ten public names of the city: Brasov, Brasso, Stalin, Perava, Stefanopolis, Corona, Brashiev, Brasov, Krunen and Kronstadt.

The Romanian and current name of the city, attested from the Middle Ages, leads to a hard-working Romanian community, not far from hard work and without courage, and which, through its merchants, gave, since the fifteenth century, the richest taxpayer of the city. From the aforementioned circle starts another northeast line from where we can note the name Brassó, which points entirely to an old community of the city (the second in size at present), which has grown spectacularly through the influx from the Szekler area at the end of the 19th century, with the first industrialization. [...]

The second line can shock because it goes east and has the name Stalin, one that points to the period between 1950-1960, when the city was called like this, when the second industrialization took place. [...]

The next line, also clockwise, has the name Perșava, the Turkish name of Brașov. [...]

A line with the name Stefanopolis leaves the circle to the southeast and leads us to the Greek heritage of Brașov. [...]

The next line goes south and ends with the Bulgarian name of the city, Brashiev, because Bulgarian builders participated in the building of the Black Church [...] With reference to the coat of arms of the city we can imagine at the end of the next line, facing south-west, the name Corona, the Latin name of the city that leads to the line of Catholicism to Rome [...] 
Another line that goes west has at its end the name of Brașovia, under the citadel from Tâmpa, torn down for military reasons, is known [...]

The next line is to the northwest and leads us to the name of Krunen, the Saxon dialectal name of Brasov, with reference to the colonists named generically Saxons from the territory of the German Empire, [...]

The last line that goes north has at its end the German name Kronstadt, which comes to complement the Saxon dimension [...]

The city also hosted Jews, Armenians, Roma, Italians and other nations, with their fascinating stories, a Danish emigrant being the first to decorate a Christmas tree in Brasov.

(The Strategy for Culture of the Municipality of Brașov 2015-2030. Synthesis)

What stands out from the concept proposed by Daniel Nazare, is the variety of names, identifications that have been attributed to the city of Brasov over time. And then we can ask again the question "What is the identity of the city?" And how does this variety of names influence the way in which the inhabitants identify themselves. In the same Strategy for Culture of Brașov Municipality 2015-2030, Oltean, (2017, 326-327) proposes another concept, "Opera Prima - first book, first school, first grammar in Romanian, first print ..."

Brasov claims the right of European capital of culture through two other cultural sectors: the school and the church. Both the honorary secondary school and the first Romanian school, as well as the Church of St. Nicholas and the Black Church, which concentrated around them national and universal cultural values. The old book collections of these institutions, are standing as testimonies.

Just voting on a winning concept is not enough and community involvement should be stimulated, as the main factor for a successful action (Nechita, 2015). The Corona Consortium has been actively involved from the very beginning in the application process. They organized a meeting of the volunteers, a "Call to action", in order to popularize the candidacy of the city of Brasov for the title of European capital of culture, at which 7 interested persons were presented (BrasovRomania.net, 2015). This raises the question of whether or not the people of Braşov identify with this action or with the proposed concepts.

The application file for the city of Brasov was submitted with another concept, about which the inhabitants of Brașov knew nothing and which was not subjected to public debate, namely 'Mountain Civilization', a kind of 'integration' of all six concepts originally proposed. In the process of voting of the 6 concepts 1343 people participated. So, the 1343 votes given by the inhabitants of Brașov interested in this topic were totally ignored. In this context I ask myself the question: How does the desire of citizens to get involved in the life of the community influence, and how does it stimulate such actions organized by the local public administration? And, in relation to Schopflin's theory about identity, if the civil society is not stimulated to act, how does this affect the identity of the city? 
At present, we also know the reasons (BZB.ro, 2016) why Brasov lost the international competition, and didn't even make the short list: the preparation of the application file started late (in February 2015, considering the fact that on December 7, 2015 the first evaluation took place), as opposed to Cluj where the cultural offer was built over several years, and elements of local identity, proximity, such as Dracula were not used (being instead used by Baia Mare (which was short- listed for evaluation from December 7).

Also, on this occasion (of the candidacy) the local administration of Brașov made for the first time (BizBrasov.ro, 2015) a barometer of the consumption of culture locally and a cultural strategy of the city was suggested for the first time. For comparison, the city of Sf. Gheorghe (Covasna County) has been doing this for 5 years.

In my action to create an inventory of the events organized in the city of Brasov, I discovered that there is no strategy, neither public nor private, in their communication. Thus, on various information channels (websites, blogs, print media, TV and radio) they are presented sporadically and unitarily. Most of the identified events are addressed to a small audience in terms of number and are of the type of art exhibitions, plays, symphonic music concerts, video projections, etc. and small events in the central square (Piata Sfatului in Romanian).

There are events addressed especially to the locals, who do not have the capacity to mobilize large masses of tourists, as is the case with the International Theatre Festival in Sibiu, the Medieval Festival in Sighisoara, Transylvania International Film Festival Cluj or the Peninsula Festival (also Cluj). In conclusion, the events in Brasov are 'quiet', which confirms the result of the study conducted for the Association for the Promotion and Development of Tourism in Brasov County (APDTBv), a study that I will present below.

In the Strategy for Tourism and Sustainable Development Brașov 2020 (APDTBv, 2013) proposed to APDTBv, the consulting company TotallyH presents a comparative analysis of the perceptions of professionals in the field of tourism (hoteliers, travel agents and public administration personnel) regarding the cities of Sibiu, Cluj, Brasov and Bucharest.

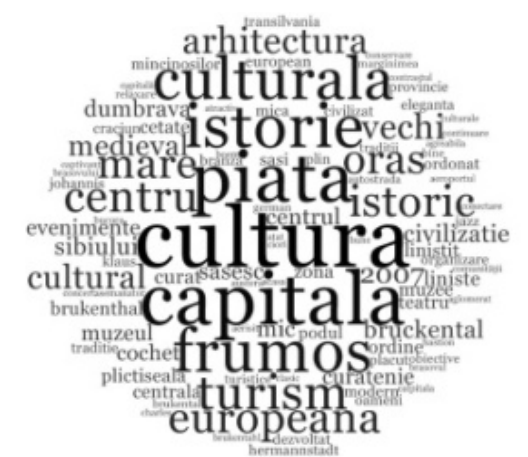

Fig. 1. Perception of the city of Sibiu

Main words in Figure 1: culture, capital, square, history, beautiful, tourism, European

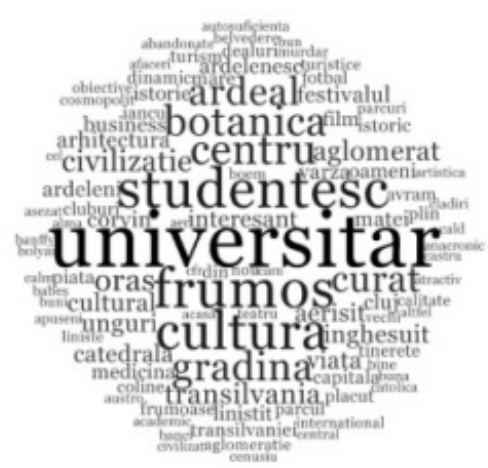

Fig. 2. Perception of the city of Cluj

Main words in Figure 2: academic, students, culture, beautiful, centre 


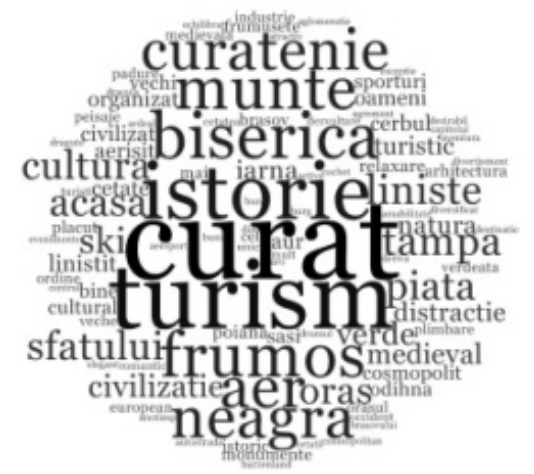

Fig.3. Perception of the city of Brasov

Main words in Figure 3:

clean, tourism, history, Black Church, mountain, beautiful

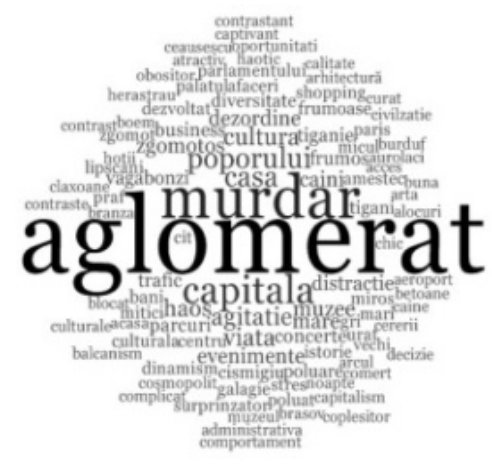

Fig. 4. Perception of the city of Bucharest

Main words in Figure 4: crowded, dirty

In the perception of these professionals, Brașov is seen as a touristic city, compared to Sibiu which is mainly identified with the idea of European Cultural Capital. Cluj is perceived as an academic city and Bucharest is perceived in the first stage as a crowded and dirty city. Because congestion and dirt are inevitable, as a perception, in a big city and in order to have a clearer picture of the cities with which it is compared, in the second stage of the analysis, negative perceptions about Bucharest were eliminated. What remains shows a dynamic city, with 'life', culture, events, parks, museums, business, etc. Performing the same operation for Brasov, but eliminating the attributes of tourism (both the word tourism and the main objectives: the Black Church, the mountain and the history), Brasov remains with 'silence', 'civilization', 'medieval' and 'green' as main perception.

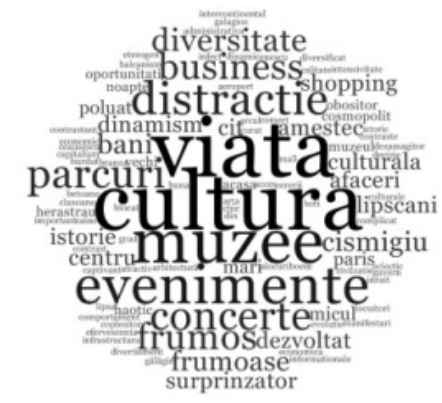

Fig. 5. Perception of the city of Bucharest, without negative elements

Main words in Figure 5:

life, culture, events, parks, museums, business

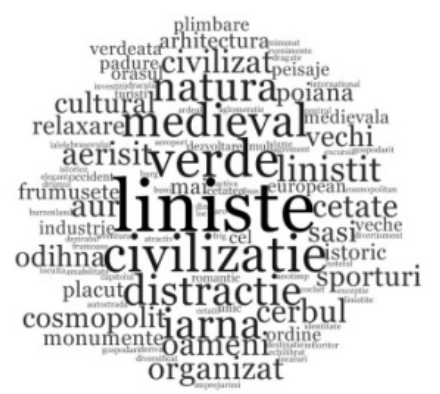

Fig. 6. Perception of the city of Bucharest, without tourism elements

Main words in Figure 6: quiet/silence, civilization, medieval, green 
What intrigues me is the word 'quiet/silence'. Not because Brașov would not be a quiet city, but because if you eliminate tourism, there seems to be nothing left. And as the TotallyH consulting company shows in their report on the strategy of tourism development in Brasov County, investments in tourism represent only $2.67 \%$ of the total investments made in Brasov County. "Thus, despite the large accommodation capacity and the relatively large number of tourist arrivals, tourism still holds a modest place in the economy of Brașov County" (APDTBv, 2013, p. 5).

\section{Conclusions}

The events that take place in Brasov have a low degree of memorability and the actions of the civil society are not encouraged at all. However, when civil society do act, they are ignored.

Starting from the premises presented by Schopflin regarding the fact that "identities are constructed through the actions of individuals, NGOs, forming currents, aspirations, opinions ... " and those of Pine and Gilmore (Pine et al., 2010) who argue in their work that "If commodities are interchangeable, goods are tangible, and services intangible, experiences are memorable. If until now people have reduced the consumption of goods to spend more money on services, today they are looking for the time and money needed to benefit from services that facilitate more memorable and valuable experiences", we can conclude that one of the reasons why Brasov does not have a strong identity of place or location and has lost all three competitions in which it participated is due to the weak collaboration between public administration and NGOs.

A city that offers memorable experiences is a valuable city in the eyes of its consumer and makes them more attached to it, as Morgan \& Pritchard (2001) stated.

The reciprocal of Schopfin's vision of identity is that a city with a strong identity has more actions of individuals, NGOs and has strong currents / opinions / aspirations. A city that has many actions and benefits from strong currents (which can be manifested politically, but also in art) is a city that offers powerful and multiple experiences and is therefore a more valuable city in the eyes of those who visit it. This paper opens the way to a new research that can validate the hypothesis that Brașov has not won any of the three competitions in which it participated due to the weak identity (also manifested by the weak collaboration between authorities and civil society and by the small number of civil society events): analyzing Timisoara, Capital of European Culture in 2021, by the number of events organized by civil society before and after 2021.

\section{References}

Botezat, D. (2012). Instituțiile și dezvoltarea socio-economică a societății [Institutions 
and socio-economic development of society]. Revista de Economie Socială [Journal of Social Economy], 1(2), 40-61.

Kerr, G. M. (2006). From destination brand to location brand. Journal of Brand Management, 13(4/5), 276-283.

Landry, C. (2013). Creativity, Culture \& the City: A question of interconnection, For the Ministry of Family, Children, Youth, Culture and Sport of the State of North RhineWestphalia, A Study of the Forum d'Avignon Ruhr, https://www.forumavignon.org/sites/default/files/editeur/ECCE report.pdf

Mommas, H. (2003). City Branding. Rotterdam: NAI Publishers.

Morgan, N., \& Pritchard, A. (2001). Advertising in Tourism and Leisure. Oxford: UKButterworth-Heinemann.

Moțcanu-Dumitrescu, M. (2011). Design-ul urban al dezvoltării durabile. Desenarea interacțiunilor dintre oameni și locuri pentru crearea unui spațiu urban de calitate [Urban design of sustainable development. Drawing the interactions between people and places to create a quality urban space.]. Urbanism. Arhitectură. Construcții [Urbanism. Architecture. Construction] 2(2), 11-14.

Nazare, D. (2017). The Strategy for Culture of the Municipality of Brașov 2015-2030, pp. 324-326, Brașov City municipality webpage: www.brasovcity.ro/file-zone/proiecteculturale/2017/Strategie\%20pentru\%20cultura.pdf

Nechita, F. (2015). Bidding for the European Capital of Culture: Common Strengths and Weaknesses at the Preselection Stage. Bulletin of the Transilvania University of Braşov, 8(1), 103-116.

Olteanu, V. (2017). The Strategy for Culture of the Municipality of Brassov 2015-2030, pp. 327-328. Brașov City municipality webpage: www.brasovcity.ro/file-zone/proiecteculturale/2017/Strategie\%20pentru\%20cultura.pdf

Pine, B. J., \& Gilmore, J. H. (2010). Economia experienței: orice afacere e o scenă și tot ce faci e un spectacol [The Experience Economy: Work Is Theater \& Every Business a Stage]. Bucharest: Publica.

Ritchie, J. R., \& Ritchie J. B. (1998). The branding of tourism destination. Past achievements and future challenges. In P. Keller (Ed.), Proceedings of the 1998 Annual Congress of the International Association of Scientific Experts in Tourism, Destination Marketing: Scopes and Limitations (pp. 89-116). Marrakech, Morocco: International Association of Scientific Experts in Tourism.

APDTBv. (2013). Turism \& Dezvoltare Durabilă - O strategie pentru Brașov 2020 / Tourism \& Sustainable Development - A strategy for Brașov 2020. www.brasovtourism.eu/upload/files/turism_si_dezvoltare_durabilao_strategie_pentru_brasov.pdf

AMA: https://www.ama.org/topics/branding/

BizBrasov.ro, 2015, https://www.bizbrasov.ro/2015/10/13/muntele-atuul-brasovuluipentru-capitala-europeana-a-culturii-conceptele-propuse-initial-considerate-de-modaveche/ 
142 Bulletin of the Transilvania University of Braşov • Series VII • Vol. 13(62) No. 1 - 2020, Special Issue

BrasovRomania.net, http://brasovromania.net/2015/08/brasovul-cauta-in-continuarevoluntari-pentru-titlul-de-capitala-cultural

BZB.ro, http://www.bzb.ro/stire/de-ce-a-pierdut-brasovul-competitia-pentru-capitalaculturala-a94604 